\title{
The Effect of Low Impact Aerobic Exercise, Mixed Impact and Training Motivation on Weight Loss Percentage of Army Wives at Batalyon Infantry 133 YS Padang
}

\author{
H Saputri ${ }^{1 *}, \mathrm{~T} \mathrm{H} \operatorname{Sin}^{1}$
}

\begin{abstract}
${ }^{1}$ Faculty of Sport Sciences, Universitas Negeri Padang, Prof. Dr.Hamka, Padang, Indonesia
*Corresponding author. Email: harmisaputri27@gmail.com,thj_sin@yahoo.com
\end{abstract}

\begin{abstract}
Based on observation, it can be seen that there were several army wives of 133 Infantry Battalion YS Padang who were overweight (obesity) due to excessive body fat. This study aims to reveal differences in the types of aerobic exercise impact, mixed impact, and motivation to practice on body fat percentage. The type of research was a quasi-experimental. The population of this research was Persit 133 Infantry Battalion YS Padang amounted to 75 women, while the sample was taken randomly with percentage technique, so that the research sample was 40 people. Motivational training data were collected using a questionnaire, and to measure body fat using Skin fold Caliper.The data analysis technique used was two-way analysis of variance (ANAVA). The findings show that (1) mixed impact aerobic exercise is more effective to reduce body fat than the low impact aerobic exercise, (2) there is an interaction between the type of exercise and exercise motivation (3) on high motivation group, the mixed impact training is more effective in reducing the percentage of body fat, while (4) on low motivation group, the low impact exercise is more effective in reducing the percentage of body fat. Hence, it was suggested to army wives of 133rd Infantry Battalion YS Padang who wanted to lose weight (Body fat) to do mixed impact training and must have high training motivation.
\end{abstract}

Keywords: Aerobic exercise, training motivation, weight loss, army wives

\section{INTRODUCTION}

A healthy and beautiful body desirable by everyone is a far more important thing to note, one of which is body fat consisting of fat cells in the thickness of the presence of fat tissue under the folds of the skin. According to Padli (2010: 59) "Body fat is the thickness of the presence of fat tissue under the folds of the skin which is measured by measuring the thickness of the skin folds in various parts of the body using a skin fold caliper". Surjadji (1996: 15) describes the percentage of body fat, namely.

"Fat will contribute to the beauty of the body, therefore the percentage of fat needs to be measured, the percentage of body fat depends on sex, age, offspring and one's activities, the percentage of fat is said to be normal if it is between $14-21 \%$ in women aged 0-30 years, the tool used is skin foldcaliper to measure one place or four places, namely the back of the upper arm (triceps), the front of the upper arm (biceps), under the shoulder blade (sub scapula) and above the kristailiaka (supra iliac).
Not only fat people who are fat and obese, even people who are thin and light weight allow excess fat, to avoid becoming fat because of the increase in fat cells in the body can take part in an aerobic exercise program.In the late 1970s a group of people studied aerobics, according to Brick (2001: 3) "There are fun but difficult aerobics classes that are very popular.During the 1970s and 1980s until now it has been completed by a fitness industry that has standardized what is safe and insecure and places which exercises provide the best results. "

Aerobic exercise is a sport for health, fitness, and pleasure, leveling goals or entering into an aerobic exercise group whose forms are gymnastic movements with warm-up sequences, core exercises and closing exercises.aerobic exercise is very easy and fun to do because it is displayed with the instructor, accompanied by music so that it gives birth to rhythmic provisions, continuity and certain duration aims to improve the ability of the heart and lungs and burn fat while improving muscle tightness. 
Based on observations, researchers looked at Padang every week or free times both morning, afternoon and evenings, almost every residential area held aerobic exercise, especially in the army wife union at 133 YS Infantry Battalion Padang. There were groups of women who do sports (physical activity) every week, in addition to aerobics, volleyball, tennis, archery is also a routine activity, one of which is to burn fat due to being overweight or overweight due to changes in cell size fat.

Nevertheless, the women who participated in aerobic exercise were only given low impact aerobic exercises even though many types of aerobics which can be done to achieve the goals of gymnastics members. Lack of understanding of the importance of an exercise program that must be agreed to achieve the goals of gymnastics members. Up to now, women who are members of gymnastics set an aerobic exercise schedule which is only once or twice a week even once a month, so that the goals of gymnastics members are not achieved.

No achievement of gymnastic member goals is also caused by motivation in training where motivation also has an important role but there are still members of gymnastics not serious in doing exercises, lack of effort and desire about the task of motion, lack of focus and slow, irresponsible to exercise commitment and being negative when the implementation takes place this is because the instructor is inexperienced and the infrastructure is not supportive.

Being overweight or overweight (obesity) due to changes in fat cell size easily attacks anyone, both men and women, seen in the army wives of the Infantry Battalion 133 YS Padang, who some of those are workers and the rest are stay at home.

Obesity is a condition that shows an imbalance between height and weight due to excess fat tissue in the body resulting in overweight that exceeds the ideal size, obesity occurs due to consuming fat that exceeds the body's need for energy and lack of opportunity to exercise or move body so that it can lead to accumulation of fat in adipose tissue and cause overweight (overweight) and even become overweight (obesity) this is evident experienced by Persit Women 133 Infantry Battalion YS Padang who is a member of gymnastics from his statement namely difficulty in moving, and clothing which does not fit anymore.

Measurements to determine body fat percentage can be done in various ways. Visually it can be known by mirroring. Meanwhile other methods can use tools such as scales and skin calipers.But the fact is that both instructors and Persit Women 133 Infantry Battalion YS Padang did not know and never measured the percentage of body fat during their aerobic exercise.

In general, this study aims to explain the phenomenon of the effect of low impact aerobic gymnastics, mixed impact and training motivation on decreasing body fat percentage in the Persian 133th Infantry Battalion YS Padang.In particular, this research is to find out. (1) Difference in percentage of body fat between low impact aerobic exercise and mixed impact aerobic exercise. (2) Interaction between aerobic exercise and motivation to practice the body fat percentage of the 133th Infantry Battalion of YS Padang.(3) The difference in the percentage of body fat between low impact aerobic exercise and mixed impact aerobic exercise in the 133rd Infantry Battalion YS Padang which had high training motivation. (4) Differences in the percentage of body fat between low impact arobic gymnastics and mixed impact aerobic exercise in the 133rd Infantry Battalion YS Padang who had low training motivation.

\section{METHOD}

The type of this research is experimental study. The purpose of this study is to see the effect of low impact aerobic exercise, mixed impact and motivation to practice on decreasing body fat percentage. To find out the motivation for training Persit Infantry Battalion 133 YS Padang used descriptive type of research with quantitative analysis approach. After that it will be continued with a 2 × 2 factorial design.

Table 1. Factorial 2x2 design.

\begin{tabular}{|c|c|c|}
\hline \multirow{2}{*}{$\begin{array}{c}\text { Exercise } \\
\text { Motivation } \\
(\mathrm{B})\end{array}$} & \multicolumn{2}{|c|}{ Aerobic Gymnastics Type (A) } \\
\cline { 2 - 3 } & $\begin{array}{c}\text { Low Impact } \\
\left(\mathrm{A}_{1}\right)\end{array}$ & Mixed Impact $\left(\mathrm{A}_{2}\right)$ \\
\hline Height (B1) & $\mathrm{A}_{1} \mathrm{~B}_{1}$ & $\mathrm{~A}_{2} \mathrm{~B}_{1}$ \\
\hline Low (B2) & $\mathrm{A}_{1} \mathrm{~B}_{2}$ & $\mathrm{~A}_{2} \mathrm{~B}_{2}$ \\
\hline
\end{tabular}

The research was conducted in the hall or in the room of the 133nd Infantry Battalion of YS Padang, starting at $16.00 \mathrm{WIB}$. This research was conducted on 28 December 2017 - 30 July 2018. The treatment was carried out in this study for four weeks with 4 meetings each week, so that the treatment for four weeks amounted to 16 meetings. In this study the population was 194 Persit Battalion Infantry 133 YS Padang.

The sampling technique in this study was carried out by using Purposive sampling techniques. The first step is to measure the level of training motivation for all members of the population. The results of the training motivation measurements are then sorted from the highest score to the lowest score. To determine the high and low categories of a score in both treatment groups, it was done by dividing group members by percentage techniques. The percentage technique in question is to settle $27 \%$ of the upper limit representing the highest score group and $27 \%$ of the lower limit representing the low score group. (Atmaja \& Tomalius: 2015). Furthermore, samples in each group were obtained from 
( $27 \%$ of $75=20.25)$ rounded up to 20 people. While subject members whose scores are above and below that category are not included in the sample. Overall the subjects involved as a sample of the study amounted to 40 people, 20 people for groups with high motivation and 20 people for groups with low motivation.

The sample was divided into four treatment groups, among others; two groups for low impact aerobic exercise with high and low training motivation categories, while the other two groups for mixed impact aerobic exercise with high and low training motivation categories. The results of the grouping of experimental samples can be seen in the table below.

Table 2. Experimental Result.

\begin{tabular}{|c|c|c|c|}
\hline \multirow[b]{2}{*}{$\begin{array}{l}\text { Motivation } \\
\text { Practice }\end{array}$} & \multicolumn{2}{|c|}{ Types of Aerobic Exercise } & \multirow[b]{2}{*}{ Total } \\
\hline & $\begin{array}{l}\text { Low Impact } \\
\text { (A1) }\end{array}$ & $\begin{array}{l}\text { Mixed Impact } \\
\text { (A2) }\end{array}$ & \\
\hline Height (B1) & 10 & 10 & 20 \\
\hline Low (B2) & 10 & 10 & 20 \\
\hline & 20 & 20 & 40 \\
\hline
\end{tabular}

Statistics Hypothesis

This type of research is experimental research which follows the following rules:

1. $\mathrm{H}_{\mathrm{o}}: \mu \mathrm{A}_{1}=\mu \mathrm{A}_{2}$

$\mathrm{H}_{\mathrm{a}}: \mu \mathrm{A}_{1}<\mu \mathrm{A}_{2}$

2. $\mathrm{H}_{\mathrm{o}}: \mathrm{A} \times \mathrm{B}=0$

$\mathrm{H}_{\mathrm{a}}: \mathrm{A} \times \mathrm{B} \neq 0$

3. $\mathrm{H}_{\mathrm{o}}: \mu \mathrm{A}_{1} \mathrm{~B}_{1}=\mu \mathrm{A}_{1} \mathrm{~B}_{2}$

$H_{a}: \mu A_{1} B_{1}<\mu A_{2} B_{1}$

4. $\mathrm{H}_{\mathrm{o}}: \mu \mathrm{A}_{1} \mathrm{~B}_{2}=\mu \mathrm{A}_{2} \mathrm{~B}_{2}$

$\mathrm{H}_{\mathrm{a}}: \mu \mathrm{A}_{1} \mathrm{~B}_{2}>\mu \mathrm{A}_{2} \mathrm{~B}_{2}$

Data analysis technique

Data obtained from the research results were analyzed using two-way analysis of variance (anava) and followed by the Tuckey test if there was an interaction between exercise motivation variables and variable types of aerobic exercise. Before the data is processed using variance analysis techniques, first anava requirement test is carried out, namely normality using the Lilliefors test and the variance homogeneity test using the Bartlett test with a significance level of $\alpha$ $=0.05$.

\section{RESULTS AND DISCUSSION}

In this section, we will present a description of the body fat percentage data of Persit 133 Infantry Battalion YS Padang which is the result of measurements of all research subjects. Based on the experimental research design carried out, there were 8 (eight) groups of members whose body fat percentage scores needed to be described separately.
Test Requirements Analysis

The hypothesis testing in this study was carried out by using two-way analysis of variance (ANAVA). As a requirement, it is necessary to test the normality and test for variance homogeneity.

Normality test

Based on the results of the calculation of the normality test of the eight study groups above, it was found that the observed price (Lo) obtained was smaller than the Ltable price at the 0.05 significance level. Thus it can be concluded that all groups of data in this study were drawn from populations that were normally distributed so that they could be used to test the research hypothesis.

\section{Homogeneity Test Variance}

Other analysis requirements needed in this study are testing the homogeneity of variance. The variance homogeneity tests carried out in this study were: (a) testing the homogeneity of body fat data from two treatment groups, namely between low impact aerobic exercise groups and mixed impact aerobic exercise groups (A1 and A2), (b) testing of fat data homogeneity the body of the high-motivation training group and the low category training motivation group (B1 and B2), (c) testing the homogeneity of the four cell data in the study design, namely cell groups A1B1, A1B2, A2B1, A2B2.

Testing of body fat data homogeneity between low impact aerobic exercise groups and mixed impact aerobic exercise groups (A1 and A2) Based on the results of statistical calculations, the largest variance (S2) is obtained with 22.0 and the smallest variance is 12.8. The homogeneity index of variance between the two groups tested (Fh) is 1.72 , while Ft $(0.05: 20.20)$ is 2.16 thus $\mathrm{Fh}<\mathrm{Ft}$ which means that Ho is accepted. In other words, it can be said that two groups are tested, namely groups $\mathrm{A} 1$ and $\mathrm{A} 2$ are homogeneous.

While testing the homogeneity of body fat data in the high category of motivation groups and low category exercise motivation groups (B1 and B2) from the calculation shows that of the two groups compared the largest variance (S2) is 20.0 and the smallest variance is 14.6. The homogeneity index of variance between the two groups tested Fh was 1.37 while $\mathrm{Ft}$ $(0.05 ; 20.20)=2.16$. Thus Fh $<\mathrm{Ft}$, which means that Ho is accepted. In other words it can be stated that the two groups tested, namely groups B1 and B2 are homogeneous.

The homogeneity test of variance from the four treatment data groups was carried out using the Bartlett test. The test criteria is to accept Ho if $\mathrm{X} 2$ is smaller than $\mathrm{X} 2$ table at the significance level $\alpha=0.05$. The four treatment groups in question are: (1) groups of members trained with low impact aerobic exercise with high category exercise motivation (A1B1), (2) groups 
of members trained with low impact aerobic exercise with low exercise motivation (A1B2), (3) groups of members who were trained in mixed impact aerobic exercise with high training motivation (A2B1), (4) groups of members trained with mixed impact aerobic exercise with low exercise motivation (A2B2). Summary of the results of the barlett test on the four groups above presented in the table below.

Table 3. Results of Barlett test.

\begin{tabular}{|c|c|c|c|c|c|c|}
\hline $\begin{array}{c}\text { Grou } \\
\mathrm{p}\end{array}$ & $\begin{array}{l}\text { Separ } \\
\text { ate } \\
\text { Varia } \\
\text { nce }\end{array}$ & $\begin{array}{l}\text { Combi } \\
\text { ned } \\
\text { Varian } \\
\text { ce }\end{array}$ & $\begin{array}{l}\text { Price } \\
\text { B }\end{array}$ & $\begin{array}{l}X \\
2 \mathrm{~h}\end{array}$ & $\begin{array}{l}X^{2} t \\
(0 . \\
95) \\
(3)\end{array}$ & $\begin{array}{l}\text { Inf } \\
\text { or } \\
\text { mat } \\
\text { ion }\end{array}$ \\
\hline $\mathrm{A}_{1} \mathrm{~B}_{1}$ & 8.0 & \multirow{4}{*}{10.00} & \multirow{4}{*}{36.00} & \multirow{4}{*}{$\begin{array}{l}1 . \\
3 \\
8\end{array}$} & \multirow{4}{*}{$\begin{array}{c}7.8 \\
2\end{array}$} & \multirow{4}{*}{$\begin{array}{l}\text { Ho } \\
\text { mo } \\
\text { gen }\end{array}$} \\
\hline $\mathrm{A}_{1} \mathrm{~B}_{2}$ & 15.1 & & & & & \\
\hline $\mathrm{A}_{2} \mathrm{~B}_{1}$ & 9.0 & & & & & \\
\hline $\mathrm{A}_{2} \mathrm{~B}_{2}$ & 7.9 & & & & & \\
\hline
\end{tabular}

By looking at the table above it can be seen that Ho is accepted (X2 count $<\mathrm{H} 2$ table). This means that there is no difference in variance between the four groups tested or in other words that the four groups of body fat data tested turned out to be homogeneous.

\section{Hypothesis testing}

The hypothesis testing of this study was carried out by two-way ANAVA technique. Then carried out further tests using the Tukey Test. The use of two-way ANAVA technique aims to determine the individual contribution of the independent variable to the experimental results (main effect) and to determine the interaction effect (interaction effect). The main influences in this study are; (1) the effect of low impact aerobic exercise and mixed impact aerobic exercise on body fat percentage, (2) the effect of high and low exercise motivation on body fat percentage. While the influence of interaction is a combination of the type of exercise and motivation to exercise on body fat percentage. The results of data analysis calculations are presented in the table 4 :

Based on the summary of the results of the two-way ANAVA calculation on the table 4, it can be stated that: 1) The hypothesis that overall body fat percentage of members trained in mixed impact aerobic exercise is more effective in reducing body fat than those who are trained in low impact aerobic exercise. accepted, because the calculation results show that Fcount $=$ 6.43> Ftable $=4.08$. with differences in the average A1 aerobic exercise Low Impact 16.35 smaller than A2
Mixed Impact aerobics gymnastics 16.90; 2) The hypothesis that there is an interaction between the type of exercise and the motivation of exercise in its effect on body fat percentage, is accepted. Because the calculation results show that Fcount $=22.81>$ Ftable $=$ 4.08. It can be concluded that there is an interaction effect between the types of exercises with motivational training on the percentage of body fat of the 133th Infantry Battalion of YS Padang.

Table 4. Summary of Two Path Anava Results on Body Fat Data.

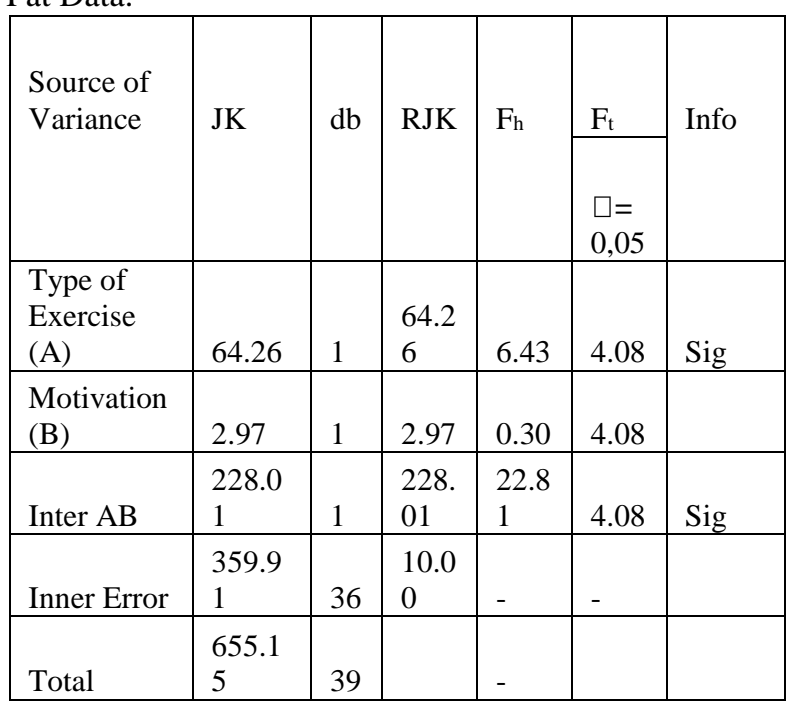

\section{Information}

JK : sum of squares

$\mathrm{Dk}$ : degree of freedom

RJK : average number of squares

RJKD : average number of squares in

$\mathrm{F}_{\mathrm{h}} \quad:$ Fcount

$\mathrm{F}_{\mathrm{t}} \quad: \mathrm{F}_{\text {tabel }}$

* : Significant

With the proof of the research hypothesis which states that there is an interaction effect between the type of training and the motivation of training on the percentage of body fat of the mothers PERSIT 133 YS Infantry Battalion Padang, the analysis needs to be continued with the Tukey Test.

\section{Advanced ANAVA Results with Tukey Test}

Based on the results of further tests using the Tukey Test above it can be stated that: 1) The third research hypothesis states that in the high motivation training exercise, the body fat percentage of members trained with aerobic mixed impact exercise with high motivation category (A2B1) is higher than those who are trained with low impact aerobic exercise with a high motivation category (A1B1), be accepted. The average score for group body fat percentage of A2B1 $=20.55$ was significantly higher than the average body fat percentage score of group members A1B1 = $15.23(\mathrm{Qh}$ 
$=5.32>\mathrm{Qt}=3.88)$; 2) The fourth research hypothesis states that in the low-motivation training category, the percentage of body fat trained with low impact aerobic exercise (A1B2) is higher than those trained in mixed impact aerobic exercise (A2B2). The average body fat percentage score of group A1B2 = 17.47 was significantly higher than the average body fat percentage score of group members A2B2 $=13.24(\mathrm{Qh}$ $=4.23<\mathrm{Qt}=3.88$ ).

Discussion of Research Results

After analyzing the data by using the two-way ANAVA approach and followed by the Tukey Test on the four research hypotheses proposed, the four hypotheses are accepted and can be tested for truth. The research findings as stated in the previous section are the results of statistical data analysis that need to be studied further to be able to explain the accepted research hypothesis, why there can be significant interactions between the types of training and training motivation, and so forth. Based on the interaction data that the treatment group obtained the highest average body fat percentage score. The following will explain each acceptance of the hypothesis.

Overall, groups that do mixed impact aerobic exercise are better at decreasing body fat percentage than those who do low impact aerobic exercise.

The results of testing the first hypothesis showed that overall, the body fat percentage of members who were given mixed impact aerobic exercise was higher than those given low impact aerobic exercise. In other words, the proposed research hypothesis is significantly proven. From these findings it can be argued that mixed impact aerobic exercise is more effectively used to reduce body fat than low impact aerobic exercise.

As stated in the theoretical study, mixed impact aerobic exercise is an effective method in the percentage of body fat. Because the initial weight training aims to utilize the energy of sugar (glycogen) which is still available in the liver and muscles more optimally, so that during the next exercise, mixed impact aerobics, the body has used fat as the main source in the first minute. This is in accordance with Rai opinion (2007: 26) arguing.

"Weight training is a superior way to reduce body fat and maintain fat to accumulate again. Muscles cause metabolism to become more active. The more muscle you have, the faster your metabolic rate, the more calories you burn, so that it is easier for your body to get a louder and tighter appearance. "

The same thing was also expressed by Santoso (2009: 76) that: "Combining weight training with other sports, will produce maximum fat burning. The trick is to exercise for 30-45 minutes to burn calories from carbohydrates. Use these moments to do sports other than weight training with a heart rate of around $65 \%$. This will optimize the burning of body fat.

In addition, the effectiveness of the mixed impact aerospace training program that combines the two High Impact and Low Impact movements is also supported by the benefits provided by weight training, which increases muscle mass and tissue activity which ultimately results in a high metabolic rate and more daily energy expenditure. too high. This is consistent with the opinion of Baechle (1999: 3) stating "the benefits of weight training are, maintaining muscle, maintaining metabolism, increasing tissue, and increasing metabolic rate." So mixed impact aerobic exercise is better at burning fat.

\section{Interactions Between Types of Exercises with Motivation Practice}

The results related to the testing of the interaction hypothesis prove that there is an interaction between the type of training and the motivation of training for the Infantry Battalion133 YS Padang in influencing body fat percentage, or in other words that the proposed research hypothesis is significantly tested.

In the group of members with high category exercise motivation who were trained in mixed impact aerobic exercise, they gained a higher percentage of body fat compared to the group members with the category of activating the same exercise and trained with low impact aerobic exercise. In the group of members with low category training motivation who were trained in mixed impact aerobic exercise, the difference was small compared to the group members with the same training motivation category. In other words, in this category mixed impact aerobic exercise and low impact aerobic gymnastics exercises have significant differences.

Thus, it means that there is an interaction effect between the type of exercise and the motivation to exercise on the percentage of fat. This means that the type of exercise and exercise motivation together have an effect on body fat percentage, or in other words the influence of the type of exercise on body fat percentage depends on exercise motivation. This is in accordance with the opinion of Gunarsa (1989: 93) arguing "motivation for sport is the whole drive in an individual that raises his sporting activities, oversees the smooth running of the exercise, and gives direction to training activities to achieve the desired goal".

The interaction between the type of exercise and exercise motivation as described above can be described by comparing the average body fat percentage between the four groups of members with high and low category training motivation with different treatments as follows: 
Estimated Marginal Means of Lemak

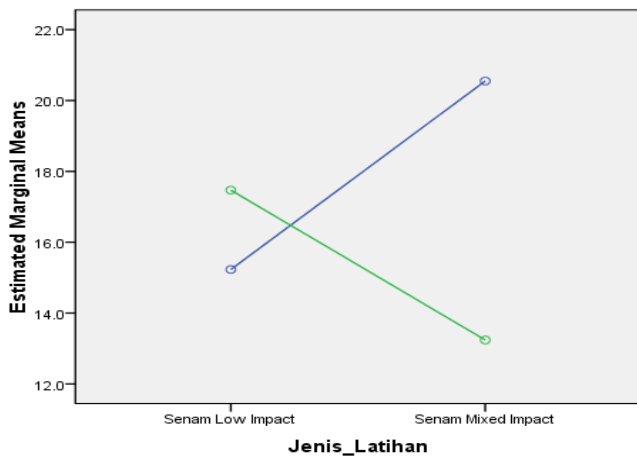

Figure 1. Interaction with types of exercises with motivation to practice.

From the histogram above it can be understood below to motivate the high category of low impact aerobic exercise exercises located on the estimated marginal means line (average score) on the $\mathrm{X}$ axis between 14.00 to 16.00 while the mixed impact aerobic exercise type is located on the estimated marginal means line (Score on average) on the $\mathrm{X}$ axis between 20.00 to 22.00 if a straight line is drawn it will be seen on the histogram above the blue line.

For the low category motivation for the type of low impact aerobic exercise is located on the estimated marginal means line (average score) between 16.00 to 18.00 while the mixed impact aerobic exercise type is located on the estimated marginal means line (average score) between 12.00 to 14.00 if a straight line is drawn, it will be seen on the histogram above the green line, after all four points have drawn a straight line on the $\mathrm{Y}$ axis (Vertical) and $\mathrm{X}$ (Horizontal) form a meeting (intersection) on the estimated marginal line means the $X$ axis is between $16: 00$ and $18: 00$. it is this intersection that proves that there is an interaction between the type of training and motivation to practice.

Noting figure 10 above, it can be seen that there is a significant difference between mixed impact aerobic exercise given to the group of members with highmotivation training exercises and those given to groups with low motivation training exercises. Likewise in low impact aerobic exercise, there are differences in the effect of aerobic exercise given to groups of members with high category exercise motivation and groups of members with low motivation training exercises.

In the exercise motivation the high category decreases the body fat percentage aerobic exercise training mixed impact is better than the low impact aerobic exercise

In the high category exercise motivation shows that mixed impact aerobic exercise is more effective than low impact aerobic exercise to reduce body fat. The effectiveness of mixed impact aerobic exercise on the motivation of high category training is due to a number of things including: (1) effective and efficient use of energy, (2) increased muscle mass and tissue activity resulting from weight training, (3) strong and persistent encouragement exercise (high training motivation), and (4) good nutrition and rest.

Mixed impact aerobic exercise is supported by strong motivation so that it can affect more quickly the percentage of body fat where mixed impact aerobic exercise is combined: one / two legs are on the floor and there is a jumping motion, accompanied by music, the duration is not less than 30 minutes with mild to moderate intensity. The amount of $\mathrm{O} 2$ needed is related to the intensity of the exercise carried out so that the body will respond with increasing amounts of oxygen sent to the muscles and heart due to heart rate and breathing frequency increasing to meet their needs, oxygen is converted to carbon dioxide which is then exhaled, the body sweats and will burn calories and fat.

These findings are supported by Jonni's opinion (2009: 10) stating "that there are several benefits and advantages that we can take in aerobic exercise. (1) A decrease in the level of harmful fats in the blood, and the occurrence of good fat levels so that it is beneficial in the body. (2) Working the heart more efficiently and being trained, so that the heart does not get tired quickly. (3) The blood vessels will get bigger so that the blood gets smoother compared to the untrained person. "This is supported by high motivation where motivation is high according to Kaupuzs (2013: 6)" The self-determination theory (SDT) concludes that motivation in promotion can encourage participation in physical activity. With an effective and energetic movement pattern for decreasing fat percentage added by high exercise motivation and the desire to reduce fat percentage by mothers, the effect of the resulting effect is more significant.

With some expert opinions above and supported by the findings of the researchers the results of data analysis using 2x2 ANOVA and continued by Tukey's test, the hypothesis proposed in chapter II empirically accepted that high category motivation is more effectively given mixed impact aerobic exercise in an effort to reduce the amount of body fat percentage to the 133nd Infantry Battalion YS Padang.

In training motivation in the low category the decrease in body fat percentage of low impact aerobic exercise is better than mixed impact aerobic exercise

In the low category exercise motivation there is an influence on body fat percentage where exercise motivation is the driving source and driver of human behavior to do sports activities (physical activity) in order to achieve certain goals and always try to do things as well as possible. In the low training motivation category, low impact aerobic exercise is 
significantly increased compared to mixed impact aerobic exercise.

The difference in influence that occurs in this low category motivation may be due to; (1) lack of encouragement and perseverance in training (low exercise motivation) so that it is adjusted to low impact aerobic exercise where the movements are not so burdensome and not so draining, (2) good nutrition regulation and encouragement in making low movements mothers prefer low impact exercise that has a variety of movements that are not so difficult and easy to follow (3) regular rest.

The research findings are supported by the opinion of Gunarsa (1989: 98). "Motivation is also included in Hedonism's theory where in essence humans will choose activities that cause feeling happy and happy. Likewise in sports, someone will only choose activities that are interesting and beneficial to him and will consider the unattractive. The facts in the field obtained in mothers who have low category motivation tend to follow gymnastics with a series of movements that are interesting and easy to follow.This is because aerobicslow exercise exercises do not provide too much weight on the body's moving organs, which is done in the absence of jumps in music accompanied by a duration of not less than 30 minutes, light-moderate intensity, so if the training motivation is low and the training is available one form of motion variation is no impact (low impact), the exercise will feel lighter than the exercise that there are two variations called mixed impact, namely minor collisions (no jumps) and hard collisions (the jump).

With some expert opinions above and supported by the findings of the researchers the results of data analysis using 2x2 ANOVA and continued by the Tukey test, the hypothesis proposed in chapter II empirically accepted that low category motivation is more effectively given low impact aerobic exercise in an effort to reduce the amount of body fat percentage to the 133nd Infantry Battalion YS Padang.

\section{CONCLUSIONS}

Based on the research findings and discussion of the results of the study, it can be concluded as follows:

(1) Overall the percentage of body fat of members who were trained in mixed impact aerobic exercise was more effective in reducing body fat than those trained with low impact aerobic exercise. (2) There is an interaction between the types of exercises with motivation to exercise on the percentage of body fat. This means that the body fat percentage of the member is determined by the interaction between the type of exercise used and the motivation to exercise the members who take part in the training process. (3) In high category exercise motivation, the percentage of body fat of members who are trained in mixed impact aerobic exercise is more effective in reducing body fat than those who are trained in low impact aerobic exercise. (4) In low category exercise motivation, the percentage of body fat of members who are trained in low impact aerobic exercise is more effective in reducing body fat than those who are trained in mixed impact aerobic exercise.

Based on the results of statistical calculations on the data obtained it can be concluded that mixed impact aerobic gymnastics training and low impact aerobic exercise can both reduce body fat. However, when viewed from the magnitude of the decline in each type of exercise applied, aerobic gymnastics training mixed a greater decrease compared to low impact aerobic exercise. This will certainly be a guideline and calculation for trainers (instructors), Persit Ibu Battalion 133 YS Padang and the community. For those who want to reduce body fat or body weight, of course the types of exercises mentioned above can be done to reduce body fat. But a more effective method of reducing body fat is mixed impact aerobic exercise. This is due to the effective and efficient use of energy and the increase in muscle mass and tissue activity resulting from weight training. In addition, mixed impact aerobic exercise does not saturate the actors because of variations in practice. While low impact movement aerobic exercise is monotonous so it can saturate and reduce exercise motivation.

Every exercise carried out should be supported by high training motivation, because training is an activity planned and arranged systematically that will be carried out continuously, for that it takes a driving source and driver of individual behavior to achieve the desired goals.

Based on the conclusions and implications above, a number of suggestions were proposed to the following parties: (1) Trainers (instructors), in an effort to effectively reduce body fat percentage members should use mixed impact aerobic exercise, because of the effective and efficient use of energy and an increase in muscle mass, tissue activity and body metabolism. (2) Persit Women of Battalion 133 YS Padang who want to reduce body fat effectively should do mixed impact training and must have a high motivation to practice, because practicing motivation is the driving source and driver of behavior to do sports activities to achieve certain goals . (3) Instructors and gymnastics members who want to lose body fat can carry out an exercise program 3-4 times a week. (4) Studios and managers can program a training program that is tailored to the goals of gymnastics members. (5) Researchers who want to examine this problem further, so that they can consider various limitations in this study, such as the number of samples, the sex of the sample and so on. The aim is for the usefulness of the findings obtained. 


\section{REFERENCES}

[1] Andini, I., \& Eka, N.S. (2016). The difference in the effect of the frequency of aerobic exercise on the reduction in body fat percentage and body weight in female members. MEDIKORA VOL. VX. No. April 1, 2016. 39-51

[2] Atmaja, N. Moh. K. \& Tomoliyus. (2015). Effect of drill training methods and reaction time on drive accuracy in table tennis games. Sports Journal. Vol. 3. No. 1. April 1, 2015. ISSN 23390662 .

[3] Azwar, S. (2014). Reliability and validity. Yogyakarta: Student Library.

[4] Bafirman. (2013). Sports Physiology. Malang: Wineka Media.

[5] Bavli, O. (2016). Investigation into the effects of eight weeks of step aerobic dance Practice on static balance, flexibility and selected basketball skills in Young basketball players. Journal of Education and Training Studies, Vol. 4, No. 5; May 2016. ISSN 2324-805X E-ISSN 2324-8068.

[6] Beck, M.E. (2011). Nutrition and Diet. Yogyakarta: ANDI Yogyakarta.

[7] Brick, L. (2001). Get fit with Aerobics. Jakarta: PT Raja Grafindo Persada.

[8] Budiharjo, Dkk. (2005). Effect of Low Impact Aerobic Gymnastics Moderate Intensity on Body Flexibility in Trained Older Women. Periodic Medical Sciences. Vol. 37. No. 4. 2005.

[9] Cahyaningrum, A. (2015). Leptin as an indicator of obesity. Prima Health Journal. Vol. 9 not February 1, 2015.

[10] Dinata,

M.

(2003).SenamAerobikdanPeningkatanKesegaranJ asmani.Lampung: Cerdas Jaya

[11] Dinata, M. (2004). Solid with Aerobics. Jakarta: Smart Jaya

[12] Firman, S. (2015). Obesity at work. CDK-231 / vol.42 no.8, 2015

[13] Duncan, L. R., Craig R. H., Philip M Wilson., \& O Jenny. (2010). Exercise motivation: a crosssectional analysis examining its relationships with frequency, intensity, and duration of exercise. International Journal of Behavioral Nutrition and Physical Activity. Vol. 7. No. 7. 23 Februari 2018.

[14] FK Universitas Airlangga. (2014). National Health \& Achievement Seminar. Surabaya: S2 Sports Health Study Program, Faculty of Medicine, Airlangga University.

[15] Giriwijayo, S. \& Sidik, D.Z. (2013). Physical Sciences (sports physiology). Bandung: PT Remaja Rosdakarya.

[16] Gunarsa, S.D \& dkk (1989). Sports Psychology. Jakarta: PT BPK Gunung Mulia

[17] Irawadi, H. (2015). Towards Athletes Mental Maturity. Padang: Sukabina Press.
[18] Jayanti, K. D. (2013). The effect of the intensity of high impact aerobic exercise, low impact, and mix impact on the physical efficiency index in terms of resting pulse rate. PENJAS Scientific Journal. Vol. 1. No. 2. July 2015. ISSN: 2442-3874.

[19] Jonni. (2003). Aerobics. Padang: Faculty of Sport Sciences, Padang State University.

[20] Kadir. (2015). Applied Statistics (Concepts, examples and data analysis with the SPSS / Liser program in research. Jakarta: PT Raja Grafindo Persada

[21] Kamal, M. (2011). Swimming Agility Education. Jakarta: Gnina Walafafa.

[22] Kaupuzs, A. (2013). The Relationship Between Physical ActivityAnd Exercise Motivation Of The First Year Students From Rezekne Augstskola. Journal Of Sport Science. 1 April 2013.

[23] Indonesian Ministry of Youth and Sports (2011). Republic of Indonesia Law No. 3 of 2005 concerning the National Sports System.

[24] Kiram, Y.\& Bakhtiar, S. (2009). Advanced Motor Learning Learning Materials. Jakarta: Sukabina

[25] Komarudin. (2015). Sports Psychology. Bandung: PT Remaja Rosdakarya

[26] Kumaresan, K., \& S. Alagesan. (2016). Effect Of Aerobic Dance Aquarobics And Combined Training On Selected Biochemical Variables Of Engineering College Students.International Journal of Adapted Physical Education \& Yoga. Vol. 1. No. 8. 26 September 2016. ISSN: 24558958.

[27] Lutan, Rusli.(1997). ManusiadanSports.Bandung: ITB and FPOK / KIP Bandung.

[28] Marheni, E., \&Purnomo, S. (2017). Sport Psychology. Padang

[29] Milne, S., Sheina, O.,\& Paschal, S. (2002).Combining motivational and volitional interventions to promote exercise participation: Protection motivation theory and implementation intentions.Journal of Health Psychology (2002), 7, 163-184.

[30] Maraz, A., Orsolya, K., Róbert, U,. Mark, D. G,.Zsolt, D. (2015). Why Do You Dance? Development of the Motivation Inventory (DMI).Plos One.DOI:10.1371. Journal Pone.0122866 24 Maret 2015.

[31] Malliou, P., Stella, R., Georgios, T., Savvas, M.,\& Georgios, G. (2013). Dance aerobic instructors' injuries in relation to external risk factors, part II. Journal Of Human Sport \& Exercise. Vol. 8. No. 3. Agustus 2013. ISSN 1988-5202.

[32] Mylsidayu, A. (2014). Sports Psychology. Jakarta: Bumi Aksara.

[33] Nawawi, U. (2014). Sports Physiology. Padang: UNP Press Padang.

[34] Nawawi, U. (2014). The effect of low impact and mixed impact aerobic exercise on percentage of 
body fat.Asian Social Science Vol. 10. No. 5. Februari 2014. ISSN 1911-2017. E-ISSN 19112025.

[35] Tarigan, N. (2017). Knowledge of balanced nutrition, physical activity and the central intensity of aerobic gymnastics participants is in the gym the riviera medan complex. Wahana of Innovation. VOL. 6 No.1. JAN-JUNI 2017.ISSN: 2089-8592.

[36] Ossanloo, P., Liza Najar.,\& Ardeshir Zafari. (2012). Effects of Combined Training (Aerobic Dance Exercises, Step Exercises and Resistance) on the Equations of Body Fat and Lipid Profiles in Sad Women at Al Zahra University. J. Exp. Bio., 2012, 2 (5): 1598-1602.

[37] PateR.R., MicClenaghan, B. \&Rotella, R. Basics of Coaching Scientific. Kasyo Dwijowinoto (translated). 1984. Semarang: IKIP Semarang Press,

[38] S2 Sports Education Study Program. (2016) Thesis Writing Handbook. Padang: S2 Sports Education Study Program, Faculty of Sport Sciences, Padang State University.

[39] Sangari, V Siva (2017). Effects of aerobic and zumba training on cardiovascular endurance among middle aged women. International Journal of Yoga, Physiotherapy and Physical Education. Volume 2; Issue 5; September 2017. ISSN: 24565067.

[40] Setiawan, Muhammad A. (2017). PerbandinganPengaruhAntaraSenamAerobikLow ImpactDenganJogging.JurnalPendidikanUnsika (JUDIKA). Vol. 5.No. 1.Maret 2017.p-ISSN 2338 - 2996.e-ISSN 2528-6978.

[41] Setyobroto, S. (2005). Pisikologi Sport. Jakarta: Jakarta State University

[42] Soekarman.R.(1986). (Untuk Pembina, pelatih, danatlit). Jakarta: IntiIdayu Press

[43] Sudjana, Nana. (2009). Dasar-Dasar Proses BelajarMengajar.Bandung. SinarBaruAlgensindo

[44] Sugiyono. (2012). Metode Penelitian Pendidikan pendekatan Kuantitatif, Kualitatif, dan $R \& D$. Bandung : Alfabeta.

[45] Sukarman, R. (1986). Basic Sports For Trustees, Trainers, and Athletes. Jakarta: IntiIdayu Press.

[46] Sumanto, A. (2009). Stay slim and healthy with diet therapy. Jakarta: PT Agro Media Library.

[47] Sumosardjuno, S. (1995). Healthy \& fit. Jakarta: PT Gramedia Main Library.

[48] Surjadji. (1996). Know Your Level of Physical Freshness. Jakarta: Center for Physical Fitness and Recreation at the Ministry of Education and Culture.

[49] SyarifzaldanWelis, Wilda.(2011). Sports Nutrition Padang: Wineka Media.

[50] Tantiwiboonchai, N., Thanomwong, K., Pongsak, Y. (2017). Effects of Muay Thai Aerobic Dance on Biochemical Bone Markers and Physical Fitness in Elderly Women. Journal of Exercise Physiologyonline. Vol. 20. NO. 1. Februari 2017. ISSN 1097-9751.

[51] Teixeira, P. J., S. B. Going, L. B. Houtkooper, E. C. Cussler, L. L. Metcalfe, R. M. Blew, L. B. Sardinha,\& T. G. Lohman. (2006). Exercise Motivation, Eating, and Body Image Variables as Predictors of Weight Control.Journal of the American College of Sports Medicine. Vol. 38, No. 1., 2006.

[52] Verducci. Frank M. (1980). Meansurement Concepts in Physical Education.California: San Francisco State University

[53] Whorter J . Wesley Mc,. Harvey W. Wallmann, \& Patricia T. Alpert. (2013). The Obese Child: Motivation as a Tool for Exercise. Journal of Pediatric Health Care. Vol. 17. No. 1., 2013. 